\title{
Performance Evaluation of Public Service Institutions (CQS) Framework
}

\author{
Nabukeera Madinah ${ }^{1}$, Ali Boerhannoeddin ${ }^{2} \&$ Raja Noriza Binti Raja Ariffin ${ }^{2}$ \\ ${ }^{1}$ Kyambogo University, Department of History and political science, Kampala, Uganda \\ ${ }^{2}$ University Malaya, P.O.Box 50603, Faculty of Economics and Administration, Kuala Lumpur, Malaysia \\ Correspondence: Nabukeera Madinah, Post graduate office, Kyambogo University, Department of History and \\ political science, P.O.Box 1, Kampala, Uganda. E-mail: nabmadinah@gmail.com
}

Received: July 12, 2014 Accepted: July 31, $2014 \quad$ Online Published: September 12, 2014

doi:10.5430/wjss.v2n1p1 URL: http://dx.doi.org/10.5430/wjss.v2n1p1

\begin{abstract}
The purpose of this manuscript is to propose three- dimensional logical research framework for analyzing shared solid waste management services performance i.e., cost, quality and social welfare (CQS) in public service institutions (PSIs) using Kampala Capital City Authority for explanatory purposes. The logical research framework encompasses almost all components involved in shared services performance like input, outputs and outcomes. Acceptable production in any PSIs should demonstrate enhancement to achieve all benchmarks. The logical framework is beneficial to practitioners and academicians for its contribution to guide bureaucrats on the need for shared services policy and its implications to government correctness in solving societal challenges through scientific measurement and hypothesizing of performance.
\end{abstract}

Keywords: Institutional performance, Shared service performance, Public service, KCCA, Performance Framework

\section{Introduction}

There seems to be a performance crisis in public service, since there is need to produce more for less. This fiscal problem strikes through poor, developing and developed has raised the appetite for efficiency, hence the need for evaluation mechanisms to help assess the performance of government institutions or programs that are quiet inadequate. This coupled with financial debt, calls for tight economic control. There is a gap in the literature on the assessment of PSIs that requires a research framework to help evaluate performance in, i) objective achievement for programs and functions, ii) policy evaluation and decision making, iii) alteration i.e., in terms of results of policy and its impact. PSIs deliver services in the breadth of any given country and assessment of their performance is unusual (Boland \& Fowler, 2000; P. Smith, 1995). Assessment for most public goods has been given little attention due to the i) difficulty in the process ii) interdependency among public institutions, iii) ambiguity of objectives, iv) definition of social prerequisite, v) diverse anticipations, vi) outcome impact, vii) insufficiencies of straight immeasurable procedures viii) national cake procedures for resource distribution, xi) failures in accountability dimension and $\mathrm{x}$ ) lack of competition.

Globalization forces worldwide, speedy alterations and an environment of fiscal and organizational performance has forced PSIs to adapt new behaviors of delivering public services since obtaining of information (Shah, 2003) has been made easy enabling citizens to seriously request for quality public goods and open the platform to competition (D. Osborne \& Gaebler, 1992; Telegraph, 2011), in order to give government correctness through addressing the test of time by taking necessary steps to measure performance of institutions hence availing importance to the definition and opportunity for assessment as a mode of performance enhancement .

The anticipated framework tries to find a solution to the existing problem by initializing a combined research hypothetical perspective of cost, quality and social welfare (CQS) in management performance among public service institutions. This suggested framework has been adapted from scholarly past works done in economies of scale, efficiency and effectiveness of shared services assessment i.e., economies of scale (Brian Dollery, Byrnes, \& Crase, 2008; Brian Dollery \& Crase, 2004; Brian Dollery \& Fleming, 2006; Kelly Leroux \& Jered B. Carr, 2007; Sørensen, 2006), efficiency i.e., (B. Bergeron, 2002; B. Dollery, Akimov, \& Byrnes, 2009; B Dollery, Byrnes, Dollery, \& Robotti, 2008; Brian Dollery, Moppett, \& Crase, 2006; Gershon, 2004; Murray, Rentell, \& Geere, 2008; Pike, 2012; Redman, Snape, Wass, \& Hamilton, 2007; Ruggini, 2006; S.M. Shakrani, 2010), effectiveness i.e., (Carter \& Greer, 
1993; B. Dollery et al., 2009; Drucker \& Wilson, 2001; FOX, Fox, \& Anderson, 1991; Ghorpade, 1971; S. P. Osborne \& Brown, 2005; Robbins \& Coulter, 1996) and Cost i.e., (Bryan Bergeron, 2003; Buchanan, 1969; Brian Dollery, Grant, \& Akimov, 2010; Quinn, Cooke, \& Kris, 2000). The model suggests an instrument for measuring public services at front office level (operational services), that electorates can use to judge performance. From the above, one is not wrong to conclude that quality and social welfare have been scientifically discarded in terms of performance assessment hence a gap to be closed.

This manuscript has five sections: An overview; a snapshot of the literature on CQS; the framework for measuring performance of PSIs; the scientific measurement and hypothesizing of performance in PSIs in Uganda and; conclusion.

\section{Literature Review on Management Performance}

Allan (P. Allan \& Movement, 2001) argued that "measuring the performance of shared services is a complex task and it is hard to supervise, tough to measure inputs and requires unique experts to monitor so that they can advise which service is suitable for sharing." Despite this, he discovered that some functions are more amendable to be shared. There is little consensus on existing acceptable criteria for measuring performance of shared services. Brain (Brian Dollery, Grant, \& Kortt, 2012), noted the lack of empirical research on the effectiveness of shared service arrangements. There is one empirical study, a thesis by (Pike, 2012), that used efficiency and economy to measure the performance of back office shared services like information technology, human resource and procurement in the English government in United Kingdom.

The English government follows headline dimensions of shared services like; (i) economy,(ii) efficiency, (iii) effectiveness and (iv) quality (v) user satisfaction (Government, 2006b). Despite the increasing interest, it is surprising that very little empirical research has actually been directed on the topic. In the literature, very few empirical studies have focused on measuring the effectiveness of shared services, particularly in public sector. More specifically at the local government level and in operational services (like waste management, water and sewerage). This may be because either analyzing or developing appropriate criteria for assessing the performance of shared services is complex and tedious process, or evaluation of performance of shared services in government departments and local government level has been ignored. This may in turn be due to; (i) nature of leadership,(ii)complex public issues,(iii)lack of commitment to change, (iv) limited resources, (v)bureaucracy involved, and (vi) it being a new phenomenon.

Needless to say, available models for evaluating shared services are relatively under developed, (Brian Dollery, Grant, et al., 2012), "while efforts to construct formal theoretical shared service models have yet to prove fruitful. Some scholars have not clarified their shared services models, while others include limited shared services options like procurement." In the literature, it is not easy to find a direct attempt of already made framework for evaluating performance of shared services. Different theorists engaged in development of the shared services concept who aim to formulate and update models that are have been unsuccessful, this has created a state of confusion and, quite often, conflicting models. Literature review is not clear on the explanatory factors or dimensions to be used when measuring the performance of shared services.

While reviewing the literature, one might find one category of research studies. The one that argues out the different criteria used as indicators or models of shared services and other dimensions that are set to measure shared services.

\subsection{The Criteria-Indicators-Dimension Models}

The United Kingdom white paper on strong and prosperous communities suggested that 'alongside efficiency, service quality can be improved by using partnerships models' boldly asserting a belief in 'significant opportunities to improve the quality and efficiency of shared services by joint work', (Government, 2006a).

\subsubsection{Measuring Shared Services by Provision and Service Production Characteristics}

(Oakerson, 1999), identified seven generic methods of production and provision of public service; (i) traditional 'in-house production' in which council provides services on its own, (ii) 'coordinated production' in which different councils come together to coordinate and collaborate on actions, (iii) 'joint production' that uses a single unit of production similar to shared service centers, (iv) 'inter- governmental contracting' where services are contracted from other councils or municipalities, (v) 'private contracting where a private entity provides public services, (vi) 'franchising' where private firms provide public services at a fee e.g. (waste management or water services) contracted to a private firm, (vii) 'vouchering' where local municipal leaders set standards, service levels and key 
performance indicators to contracted private firms. The key aspect in this model is the separation of 'production and provision' functions in local authorities. This model used a criterion of quantity, quality and cost and one of its shortcomings is that, it focused on some characteristics which are profit driven sidelining the welfare.

\subsubsection{Measuring Shared Services Using the Club Model}

Buchanan's approach to optimal provision of public goods is called a 'contract solution' where individuals are prepared to agree and accept the 'attendant tax' or 'exchange' agreement associated with public service provision (Buchanan \& Tullock, 1965). He emphasized that efficiency can be attained at a social welfare function where individuals have a stake in resource reallocation. In other words, he focused on the process of interaction between individuals in the economy. He stressed that individuals must pay because they benefit from the services provided by the local government. He established conditions for optimum output and membership. To him clubs were seen as consumption sharing arrangements that provides goods whose consumption can be excluded from non-members. He expects 'economies of scale to accrue if agents come together and share the cost of providing the public good'. The model looks at 'a real world' because it assumes 'anonymous' groups.

\subsubsection{Measuring Shared Services Using Quadrilateral Taxonomy}

(Tomkinson, 2007), used the service model of British local government which limited shared services to only procurement to classify shared services with a focus on; (i) 'intra- service', (ii) 'corporatist' that emphasizes an establishment of joint governing body, (iii)'councils that share the cost', (iv) special establishment of 'special purpose vehicle' like a joint venture company formal in nature to deliver the services to the council. In other words the body formed should be separate from the council they serve and their interests. Local governments are entitled to deliver a good range of services to the people. However the nature of services vary from one local government to another. In perspective, some services are more amendable to be shared than others (Percy Allan, 2003; P. Allan \& Movement, 2001). It can be argued that assessing shared services solely in terms of procurement or using the procurement benchmark, results into a partial measure and may not be representative of especially for operational shared services like waste management since they are not back offices in perspective. Therefore this framework of measuring may not apply to all services in the local governments. The criteria followed here was economies of scale and reduced costs.

\subsubsection{Measuring Shared Services in Terms of Inter-governmental Contracting Model}

According to Brian (Brian Dollery, Grant, et al., 2010), they classified and proposed a way derived from Australia local government. Under this model local councils, regions, sub nations, municipalities, states, federal, national governments voluntarily sign or undertake functions within the public sector to deliver services and this is commonly called public-public partnership. This kind of arrangement can be trusted since there is a common goal for all parties. He (Brian Dollery, Grant, et al., 2010), believes that this kind of arrangement will yield economies of scale, reduced cost and improved efficiency. Focus was dedicated to both informal and formal partnerships. (Brian Dollery, Grant, et al., 2010), didn't put into consideration that informal partnerships can dissolve easily as they are often formed without binding agreements. The criteria used for the intergovernmental model was; Economies of scale, Efficiency and increased production time. Therefore assessing shared services using this approach or criteria is not enough. This calls for other components to be incorporated to get a comprehensive measurement matrix for shared services.

Another approach is the Vertical Shared Services model (VSS) (Dollery and others), which uses three dimensions (economies of scale, reduced costs, efficiency), is based on the assumption that encourages coordination. This model involves cooperation between local governments/ local authorities, and the service is offered at a fee. However, it could be difficult to operationalize since it involves charges and chances are that the goal of equity in service delivery will not be achieved because end users meet the cost. Shared services can not only be assessed using economies of scale, cost and efficiency, rather other elements have to be incorporated to realise value addition in the measurement, strike balance among other competing values and organize them into an integrative framework for assessing the performance of shared services.

(Brian Dollery, Grant, et al., 2010), also proposed a horizontal shared service model by integrating economies of scale and efficiency under joint arrangements among local authorities and these range from formal to informal resource sharing. However, the in formalness of an arrangement may mean that it can dissolve easily. This shift from formal to informal approach is a critical component for supporting shared services arrangement to achieve target goals. However, operationalization to support the measuring of shared services becomes a key success factor against the used criteria of Economies of scale, Efficiency and increased production time. If we believe that shared services is the right way to solve issues, then interdependencies should be supported, (Chandra et al., 2001; Glendinning, 
Powell, \& Rummery, 2002; Hudson, Hardy, Henwood, \& Wistow, 1999; A. Smith et al., 2002).

An attempt to evaluate the performance of shared services was made by (Yee Hon Wong, Jonathan, 2009). The basic purpose of the study was to investigate the difference between shared services and outsourcing i.e. motivators, arrangements, benefits, disadvantages etc. the core objective was to develop a decision model which would aid organizations in deciding which pre-arrangement would be more suitable for them to adopt in the quest of process improvements for their operations. The context of the study was in universities of higher learning and focused on information technology which is an administrative service, hence back office services. The study adopted a production and provision Model (Oakerson, 1999) and used the qualitative explanatory approach. The study contributed considerably to the field of measuring performance in public organizations (universities) following an inter-governmental shared service arrangement, given the fact that the available framework for evaluating performance of shared services are still lacking and under developed. The dimensions used included quality, quantity, reduced cost and customer focus. This comprehensive study has a wide area of concern on operational shared services like waste management. It is a decision model recommended for the Australia's education sector, political, administrative and organizational set up. However there is likelihood that the results derived from this study may not be transferable to societies which have different political, administrative and organizational characteristics.

(Murray et al., 2008) carried out a study on corporate shared services in English government. It was a qualitative study that engaged six case studies of shared procurement functions between smaller local authorities, four out of six cases were reported to have established their arrangements in response to central government policy initiatives of shared services and efficiency gains were perceived to have been achieved (Redman et al., 2007). This study followed a mixture of a Quadrilateral taxonomy model by (Tomkinson, 2007) because of limitation to procurement as the only shared service under the study. The dimensions used were; economies of scale, reduced cost and customer focus as well as the, 'inter-governmental contracting model.

(Brian Dollery, Grant, et al., 2010), the study emphasized shared arrangement which is public- public partnership and inter-governmental in nature. The dimensions followed included economies of scale, efficiency, increased production time and equity with a focus on back office shared services and procurement in particular. Its performance is recommended for English local government sector, political, administrative and organizational set up. However there is likelihood that the results derived from this study may not be transferable to societies which are just trying to develop and highly decentralized with many tiers at the local level like Uganda.

Price water house coopers is being discussed in this project as a case study of one of the "consulting companies offering shared services to clients around the world like. At Price water house coppers, Gunn partners, whereas some failures were realized or slow success was observed by (Hogg, 2003), many "service centers that provided human resource organizations realized a 30-50 percent reduction in administrative and human resource costs" in some projects.

The biggest companies world over have some sort of sharing concept in practice in their business structures. The top six reasons companies introduced a financial shared service model in 2005, (Bangemann, 2005) are: (i) reduced administrative cost by [79\%], (ii) improved services and quality, (iii) accuracy and timeliness , (iv) $69 \%$ reduced in headcount and salary [64\%], (v) standardized service by $44 \%$ and simplified their roll-out and (vi) information technology systems support [38\%]. This was a survey done by the Hackett packard group at Ford motor company. 'Invented together with general electric' in Europe in 1980, Ford has also managed to reduce risks and costs.

The most interesting one is Henkel who started on its finance approach in 1999 but later the company grew big and purchased 60-70 companies per year. The model used was a hybrid approach (B. Bergeron, 2002), which has "characteristics of centralization, decentralization \& out-sourcing". The findings may be useful, due to the mix of different forms and structures that this research project is dealing with.

In the local government sector, very little academic research has been conducted to assess the benefits of adopting different models of shared services, (Brian Dollery, Grant, et al., 2012). A few cases can be synthesized, (Brian Dollery et al., 2008) reflecting on the Queensland undertaking local government Association (LGAQ)- group engagements and commercial activities of 2007, they recognized five diverse shared service agendas: Work care, the shared liability pool, infrastructure service, local buy-in, and partnerships group. (BE Dollery \& Marshall, 2003), also toured to supplement on the planned merger agenda. He noted that Regional organisational councils (ROCs) founded on optional and not obligatory preparations, may result into not only in improved coordination, but nurture a spirit of collaboration among bordering councils, and also do away with predictable resentment and expenditure of compulsory merger. (Brian Dollery \& Crase, 2004), acknowledged that there are great economies of scale and he emphasized the need to merge small and economically not capable (unviable) rural and regional councils into large 
merged public establishments' to realize savings.

(Pike, 2012), carried out a case study and regression analysis on how corporate shared services (information technology, human resource, procurement, accounts payables, account receivables) operate in English government. His findings were that," shared services have taken a limited form with limited impacts'. The shared service model has not been used deeply or extensively, and has largely been based around an arrangement to share the costs of senior managers." He used the 'inter-governmental contracting model' (Brian Dollery, Grant, et al., 2010). The study emphasized shared arrangement in which is public- public partnerships and inter-governmental in nature and the dimensions followed included; economies of scale, efficiency, increased production time and equity. The English government had its own dimension like; economy (cost), efficiency, effectiveness, quality and service improvement and he used a mixed method in his investigations. The type of performance study carried out by Pike is relevant for back office shared service in public-public partnerships.

In the Riverina Eastern regional organizational councils (REROC) (Brian Dollery \& Crase, 2004), got involved in thirteen local councils between 1998-2003 and identified areas in which shared services proved to be more effective including, joint tendering, purchasing, information technology, compliance initiatives and lobbying activities. It was also estimated that shared services in REROC resulted into a saving worthy $\$ 4.5$ million by reducing duplication, combined tendering, regional lobbying and cooperative sharing of services. The Horizontal shared service model used represents joint arrangements between local authorities ranging from improvised, emergency resource sharing to complete shared administration, together with the intergovernmental contracting model where local councils voluntarily undertake functions for regional/state/national governments with the following; economies of scale, efficiency, increased production time, and equity.

While the study performed investigated the assessment of Kamapala Capital City Authority, on solid waste management shared services (Madinah, Boerhannoeddin, \& Rriffin, 2014), value was added by analyzing and discussing back office shared service past studies to investigate the models used, rationale and dimensions in their study which helped in widening the scope of shared services in designing a framework. (Brian Dollery, Goode, \& Grant, 2010) discovered that shared services can bring planned savings and reduce implementation costs. He confirmed that using a shared service model "at least in Australia, had produced high viable outcomes". The forgoing intention is to ensure economies of scale through joint resource sharing. He (B. Dollery et al., 2009), asserted that most of the "previous studies in Australia were largely based on surveys and accounting estimation. He also noted that improvement of service delivery through shared services involves amenability of some functions than other" (HR, procurement and IT).He continued to assert that, there are challenges in implementations like, complex processing, conflicting objectives and uncertain benefits, (B. Dollery et al., 2009).

(Ulbrich, 2010), investigated one case study in Sweden were he looked at "people, policy and process changes associated with shared services, noting that employee resistance was very problematic". Both (Niehaves \& Krause, 2010a, 2010b) investigated two case studies in Germany were they concluded that, financial savings are the main rationale for sharing services. He gave two pre-conditions for the success of shared services: leadership support and prior cooperation.

(Pike, 2012) used un- published work to carry out a case study and regression analysis, on corporate shared services. He found out that shared services have taken limited scope and impact. (Gershon's, 2004) used bi-annual local authorities efficiency statements in the UK public service, and his findings were on most commonly cited shared services include; procurement, IT, back office functions and compliance activities. Deloitte (Harris, 2010) used accounting estimations with various cities in the UK government and recognized a number of challenges to shared services i.e., lack of knowledge, the cost of the first stock and capability, behavioral and party-political difficulties, connected to person's occupations and dangers of dropping some employees, a wish by selected associates to uphold activities for both front and back office provision tasks and opposition to sharing power among other local authorities. (Solutions, 2005), used a survey of $26 \%$ of all local authorities in England. The study recognized nine areas of highest prospective for shared services. Price water cooper (Cooke, 2006), used accounting estimations in the Anglia revenue partnership of two rural councils and results indicated they attained highest performance alongside with important savings.

(Ruggini, 2006), carried out a survey in the USA counties and his results provided examples of the more successful shared services that included among others: joint procurement, emergency services and records management. (C. V. Hawkins, 2009), in his research using case study identified three greatest causes for starting joint ventures as: improved municipality's comparative advantage, safe economic resources available and taking advantage of economies of scale. (Chen \& Thurmaire, 2010), used a case study in Iowa in USA and established reasonable sharing 
benefits among participants as a significant influence in establishing successful inter-local agreements. (C. Hawkins, 2010) also used a case study and established that economic development, joint ventures between US local authorities is subjected to a number of factors like presence of great heights of nets of people living together and frequent communication among important stake holders. (Kelly Leroux \& Jered B. Carr, 2007) used data from 468 local governments in Michigan to inspect the part played by the reasons for amplification of interlocal collaboration on public works like; financial, features of the societies around the local government, background features of the local government, and the effect of policy and preparation setups. The findings indicated that, "it's not very clear how local governments may appreciate bonuses in the form of immaterial profits and Inter-local agreements advantage to shape trust among the officials". He continued to argue that, cooperation's are more "extensively used in the delivery of local public services like waste disposal other than 'life style services' such as parks and recreation."

(Duncombe \& Yinger, 2007) used accounting estimations in various rural schools in New York rural districts and found out that consolidation makes fiscal sense, particularly for very small districts. (Sharif M Shakrani, 2010) similarly used accounting estimations in 10 counties in Michigan and found out that $8 \%$ of operations and maintenance, food services to $18 \%$ of transportation cost reduction. (Lackey, Freshwater, \& Rupasingha, 2002), used a survey and regression analysis in the Tennessee Valley and determined dynamics manipulating local government collaboration in rural areas. (LeRoux, 2008), in his analysis discovered inter-local agreements for 10 public works services, used the survey and regression method. (Kelly LeRoux \& Jered B Carr, 2007), used a survey and regression analysis in Michigan and found out that local governments frequently collaborate on delivery of a range of public works, like infrastructure expansion and upkeep(Lackey et al., 2002), used interviews and regression analysis in Tennessee valley and analyzed reasons prompting local government collaboration in rural areas.

Furthermore, (Lombard \& Morris, 2010) surveyed Northern US in Connecticut and Springfield, and Massachusetts, where he developed the idea of cooperating and how it works in practice, in which he argued that, 'the informal cooperation is truly remarkable.' (Gordon, 2009), surveyed in Missouri, Indiana, Kentucky and Tennessee valley and discovered that a 'win-lose' situation becomes a 'win-win' because of the accomplishments with increased local regional cooperation. (Carr, LeRoux, \& Shrestha, 2009) used a survey and found out that norms and values imparted by careers add to local government service production selections. (LeRoux, 2008) used accounting estimations southeast Michigan councils and noted that the empirical findings suggest that regional organizations can in fact promote inter-local services.

In Philippines (O'Leary, Gerard, \& Bingham, 2006) a survey in schools discovered that public managers now find themselves convening, facilitating, negotiating, mediating and collaborating across boundaries. New Zealand (McKinlay, 2011), used a case study in Waikato region and identified the potential of shared services in Boplass and appreciated the way they conceptualized the idea of shared services centers of excellence which will reshape the way local governments address shared services too.

\section{Framework for Management Performance}

Literature review has discussed the past studies in section 2.4.1 above and its evident that some scholars have tried to make group investigations and tested the claim that shared services improve performance and provides quality services like; (Murray et al., 2008; Niehaves \& Krause, 2010b; Redman et al., 2007; Ruggini, 2006); (Murray et al., 2008), (Niehaves \& Krause, 2010b) and (Ruggini, 2006), yet some cases focused on costs and creation of economies of scale, (Brian Dollery \& Crase, 2004; Brian Dollery, Grant, et al., 2010; Brian Dollery \& Johnson, 2005), other studies discovered conditions that facilitate application and setup of shared services like trust, relationships and prior cooperation, (Niehaves \& Krause, 2010b). Others that echoed the same are; (Andrews \& Entwistle, 2010; Guo \& Acar, 2005; Lackey et al., 2002; Lasker, Weiss, \& Miller, 2001; Turrini, Cristofoli, Frosini, \& Nasi, 2010) and (C. V. Hawkins, 2009), also mentioned three factors influencing collaboration.

The literature review has outlined the basis for shared services and the expectations like economies of scale, reduced cost and improved performance among others. Secondly research availed the models that may have characteristics of the above mentioned arrangements which may influence the performance of shared services. Additionally, the literature review on shared services within the public sector is limited. This was observed by (B. Dollery et al., 2009; Brian Dollery, Grant, et al., 2012; Brian Dollery, Kortt, \& Grant, 2012), who noted thus "little scholarly effort has been directed at empirical analysis of the characteristics of shared services models in practice". However, he not only appreciated the fact that shared services have a great potential in Australia government but also he decried the policy shift to effectively support the smooth performance of shared services. This was also echoed by (Symons (Symons, 2011), who pointed out that "shared services have been characterized by an approach of limited scope". The purpose 
of this paper is to assess a framework for measuring shared services in PSIs and evaluate how shared services perform were ever they are through an integrated model .By broadening the scope for which shared services are assessed, there is hope that shared services will move on to another level of perspective and hence increase its form and impact as proved by (Pike, 2012), that," shared services have taken a limited form with limited impacts'. The shared service models have not been used deeply or extensively, and has largely been based around an arrangement to share the costs of senior managers."

Largely, the review of shared services engagements through both private and public sector discloses that there is inadequate published works on the effectiveness of a diversity of shared service models and engagements. According to the literature, some single cases have been a success factor in highlighting the features in the operation and performance of shared services preparations., (Brian Dollery \& Crase, 2004; Brian Dollery, Grant, et al., 2010; Murray et al., 2008; Pike, 2012; Redman et al., 2007). It should be observed that evidence is not very clear due to the nature of phases used 'shared service may result into reduced costs'; this is as a result of limited scope given to shared service hence a clear gap to be investigated. What obviously rests unspoken though, is the degree to which these preparations are fruitful and the outstanding-exhaustive issues that may add to the relative success of the varying models of collaboration. There is a strong requirement for investigations to empirically examine the effective performance, to update the diverse forms of shared service models, the characteristics of shared services, the features that are necessary to safeguard continuity, and the consequences that can be most desired, projected as a function of commitment of shared preparations.

It's important to place this research in the context of previous work on shared services. Past studies have been anlaysed, models have been identified and assessed to determine whether shared services has lived to its promise take an example of (C. Hawkins, 2010; C. V. Hawkins, 2009).The previous works form the basis of further research projects and novelty for new ideas and hence contribute to the one going debts. Most of the principles and approaches deliberated in the review of the literature under section 2.1.4 have been merged and arranged in this contemporary study to come up with an integrative and composite framework of CQS for measuring performance of shared services in public service institutions. CQS is important in apprehending performance in government departments. Any public service institution to claim that it is performing well, it should use the integrated model of CQS that is further developed into (SSEEEEQQ) (Madinah, 2014) and summarized into the three dimensions i.e., service costs, service quality and service equity (SCSQSE) must be achieved instantaneously. The three dimensions are presented in in-depth below;

\subsection{Standardization (S1)}

A service standard refers to a civic assurance to a quantifiable level of production that clienteles can imagine in usual conditions. Similarly in division councils consistent standards and common business systems are practiced. What we are not sure of is whether they result into economies of scale. The world is a rapid period of change where the social changes and technologies have replaced all the old customs of postal service, three news magazines, and one television network. Now the public monopolies are joining to survive the test of time and the only way they can survive is by replacing bureaucracy with entrepreneurship, (D. Osborne, 1993). The possibilities of standardization and the uniform way of working increases the efficiency, together with consolidation, making it possible to afford required technology investment (Ulbrich, 2003).

\subsection{Social Welfare (S2)}

More specifically Social welfare programs are in place to support people from distress and poverty. In most cases they are temporary and sometimes include services from the non-government organizations using different professional personnel to help people in their societies. In the modern world, no society can afford not to take welfare services seriously because they will be neglecting the well-being of the public hence a quest for social justice (Dolgoff, Feldstein, \& Skolnik, 1980). Besides governments need to increase the economic efficiency through education, health, and other means. Gutmann,1988, as cited in (Dolgoff et al., 1980) points out that social welfare activities are not the category of perquisites in society like security where government is mandated to keep the people and their property safe, but services that meet immediate needs of individuals and families such as counseling, subsidizing housing, hospitals , primary health care and schools. Sharing of services embraces fairness and equal treatment among the programs and services delivered.

\subsection{Economies of Scale (E1)}

For the Economies of scale, there is an aspiration for the lowest level of production, and delivery of resident public services involves a definite number of people support to attain. In his support, (B Dollery et al., 2008; Brian Dollery \& 
Crase, 2004), acknowledged that economies of scale emphasize the requirement to merge small and economically 'not capable' countryside and national councils into bigger combined metropolitan administrations and in the setting of the best size of municipalities, economies of scale usually refer to a proportionate saving in costs gained by an increased level of production of service as the population served increases.

Thus in effect, a lot of works has emerged on various different representations of local governance accustomed to encounter the varied conditions, and most of the architects of these models labored to provide a supporting rationale. Nations repeatedly trust that cost effectiveness (efficiency) can be enhanced by merging current small local divisions into bigger local establishments. For example (Sørensen, 2006) argues that bigger establishments can utilize economies of scale and scope; because they have more resilient financial foundations and higher maximum power to deal with additional or extra responsibilities, yet the small units are 'unviable' to deal with key demands because they lack maximum power to deliver many expert public services. This argument was supported by (B Dollery et al., 2008; Brian Dollery \& Crase, 2004; M. Warner \& Hebdon, 2001), claim that the public-public partnership model 'permits Countries to attain economies of scale when governments retain provision possession of services in the public sector'.

However, this argument of improved economies of scale is not without certain amount of criticism even among its ardent supporters like (Brian Dollery \& Fleming, 2006), who points out that in general employment concentrated, client-positioned services, such as community rangers, health inspectors, etc., make insufficient scale economies since they are an individualistic natural world. And in particular, the higher the demand for services, the increment in number of employees. In addition there will also be diseconomies of scale and according to scholars in shared services, it can be measured through freeing up management resources, minimizing administrative costs and, creating a critical mass support of activities to enhance benefits of shared services associated to scale argument.

\subsection{Efficiency (E2)}

The efficiency of public service organizations has been under a high level of inquiry in contemporary world for many years. Efficiency is doing things right. It deals with attaining the goals of the proposed action at least cost and within a prescribed period and through proper use of assets. Hannington Emerson (in the beginning of the $21^{\text {st }}$ century) defined efficiency as a relationship between what is accomplished and what might be accomplished. This explains how much the system absorbed (cost) and how much of inputs emerges as the product (output). So it simply relates on how an organization converts inputs into outputs without wasting resources for . In local governments there is wastage since there is no competition and worry for takeover or merger in case of failure. Quantifying inputs and outputs is one way to measure efficiency and this is easy for profit generating organization (Moharir, 1997).

In this framework, 'shared services are the means through which to achieve greater efficiency' (NAO, 2007). Evidence related to the advantages of local authorities working with in partnership with other public services suggests that public-public partnerships are associated with 'public service efficiency,' (Andrews \& Entwistle, 2010). Partnerships are known as a key tool of policy makers, supposedly providing mechanisms to improve service efficiency.

McQuaid (McQuaid \& Scherrer, 2010) reviews a number of paybacks linked in collaboration with numerous features linking closely to the scale argument: sharing knowledge, expertise and resources, pooling of resources to 'increase the total level of resources brought to bear on problems', improving efficiency and removing duplication.

Theorists argue that, scale leads to provision of experts, technical equipment hence efficiency (Andrews \& Boyne, 2009; Boyne, 1996) argues that due to the concentration, the equipment can be procured at lower costs hence group buys and then shared by all the partnership or single large organizations.

\subsection{Effectiveness (E3)}

The concept of effectiveness has been a theme of too much dispute and has been understood in different ways (Ramanujam, Venkatraman, \& Camillus, 1986). It can be defined as the degree to which organizational objectives are achieved, from the literature one can say that doing the right things (Robbins \& Coulter, 1996) that yield results is indicative of effective organization.

According to (Carter \& Greer, 1993), effectiveness is the degree to which proposed action (policy) impacts connect to proposed action goals. (Jreisat, 1997; Lusthaus, 2002; Mulreany, 1991) defined effectiveness as an extent to which outputs attain goals or proposed action objectives. Effectiveness links to proposed action outcomes and proposed action aims and also relates outputs to outcomes. (Jackson, 1995)argued that, effectiveness is the correlation among the calculated outcomes and the true outcomes of any programs. 
The effectiveness of the shared services arrangement is also believed to be dependent on the effectiveness of the implementation process (Borins, 2001; Piening, 2011). Trusted Partnerships between public services may be formed to address a complex social challenge, with two or more public providers working across their organizational boundaries to address the challenge and improve service effectiveness (Andrews \& Entwistle, 2010). In addition, the model is theorized to benefit from reduced supervision costs, owing to trust and goal alignment between government partners (T. L. Brown \& Potoski, 2003; M. E. Warner \& Bel, 2008). In this framework, 'shared services are the means through which to achieve greater effectiveness.

\subsection{Equity (E4)}

Equity is a moral conception that dodges precise definition. The Substitutes are community justice or fair play, equitableness, which definitely represent diverse things to different people at divergent times. Equity involves the wants not societal benefits that are examined in resolutions concerning capital distribution. Equity is not equality; inequities are imbalances which are determined to be discriminatory, i.e., unjustifiable and preventable. Equity is looked at as requiring a sharing of progress in the society (Braveman, 2011). In other words extending the services to those who are in dare need or equal accessibility of solid waste management services. Equality means that you treat everyone equally while equity means that such actions should be taken to make all people come at equal level to approach the future opportunities equally. For example, if you have ten garbage skips and you want to give to two different groups of people, then equality is that you divide them half among both the poor slum residents and the rich residents, but equity is that the those residents who never had chance to have a garbage skip from many decades, should be given more garbage skips first so they can also gain the equal benefits while the remaining skips are divided equally among both.

In solid waste management equity has been defined as; " the present generations having better equality in accessibility to ecological resources and ought to share the charges and profits related to people's actions (i.e., contamination of the environment, health care) in a new justifiable manner" (Mitchell, May, \& McDonald, 1995). Thus, if the world's people do not have equal access to resources and environmental services, this can lead to environmental degradation (Bahia, 1996).

\subsection{Cost (C1)}

According to Buchanan (Buchanan, 1969) cost is seen in the perspective of a decision maker; cost is benefit lost or an opportunity sacrificed by the individual, group, and government. The amount of money that a company spent on the creation or production of goods or services.

According to (Quinn et al., 2000), the need to deliver cost reasonable choices is what helps the inside provision to appreciate what their real costs stand in delivering services and benchmarking their costs alongside practices from a number of other organizations. According to him, there are four key cost components that require consideration in any shared service partnership. (i) service and labour costs, are the costs incurred for delivering a service on a client's behalf such as transactional cost processing and advisory professional services, (ii) Governance labour costs, which are associated with developing new corporate policies, procedure, standards done on behalf of top management, (iii) Administrative costs, costs for carrying out day to day work activities in an organization like meeting facilitation and attendance, (iv) overhead cost incurred when facilities are used as group to coordinate activities like internet, telephone, computer etc.

\subsection{Quality (Q1)}

Literature provides a abroad approach to the definition of quality, which can be confusing at times because of the relativity of the definition. As noted by Imai, quality is a concept that is perceived differently in context to different people and this explains why there is a slight consensus on what comprises quality. In its widest wisdom, 'quality is everything that can be revamped'. (Deming, 1994) did not give his own definition on quality but closest to his definition is, 'quality must target the consumers' current and forthcoming requirements'. (Juran, 1988), is well recognized for explaining quality as, 'suitability for usage which he terms as the degree to which an outcome positively performs the purpose of the consumer'.(Crosby, 1979) on the other hand, defines quality as 'conformance of requirements'.

(Feigenbaum, 1999), added the service factor into quality which he explained as, 'entire complex product and service attributes of advertising, designing, producing and preservance along which the product and service used will encounter the prediction of the client. (Garvin, 1988) definition of quality has been widely quoted in the literature as being among the first attempts to define quality in a comprehensive manner. He defines quality from five approaches which are the "transcendent approach, product -based approach, user-based approach, manufacturing- based 
approach, and value-based approach'. Quality can also be equated with other dimensions as well, such as responsiveness, competence and communication.

(Parasuraman, Zeithaml, \& Berry, 1988) acknowledged five measurements of service quality which are; "tangibles, reliability, responsiveness, assurance and empathy". There are instruments for measuring service quality, known as SERVQU that have been widely used by researchers in measuring customer awareness of service quality. The global population is growing and thus leading to growing demand for various services as people become increasingly specialized in their respective skill, services are at the center of financial activities in any society that provides the essential links to many other sectors of the economy.

\subsection{Quantity (Q2)}

A quantity of something, typically the total of anything or a phenomenon, expressed as a numerical value. Theorists of shared services have advised, due to the difficulties in measuring quantity, unscrupulous vendors can supply less quantities in order to provide competitive prices. (Trevor L. Brown, Potoski, \& Van Slyke, 2006), assert that, some services are hard to measure because they put government in a helpless position with unprincipled dealers who the principal agent theory suggests, could abuse their knowledge benefit through reducing service quality and quantity. So governments are likely to employ joint contracting or contract with organizations that share their vision.

\subsection{Operationalizing of Theoretical Framework}

By adapting CQS (SSEEECQQ) as a study framework, a narrow concept of evaluating shared services depending cost reduction, efficiency and economies of scale is looked at in a broad approach where measurement of performance is linked to three main and nine sub dimensions of CQS (SSEEECQQ) i.e. (standardization, social welfare, and efficiency, economies of scale, effectiveness, equity, cost, quality and quality).

\section{Institutional Performance (IP)}

In other words, the CQS (SSEEECQQ) point of view takes into account multiple dimensions which may influence the performance of shared services instead of the single dimension. The framework of CQS (SSEEECQQ) points to how the various dimensions interact to create the outcome that is suitable and relevant and would further enhance the effort of evaluating performance of shared services. The study does not only present a model to assess the performance of shared services, but also how to operationalize it by developing different sets of performance indicators for the quantification of shared services and how to as well implement it by taking Kampala Capital City Authority with five divisions as a case study.

\subsection{Evaluating Cost}

Cost can be measured through partnerships sharing overhead costs, serving a greater number of client base, as scale of production, reducing duplication of administrative costs. Principles of sharing argue that services can still be delivered even though the cost is high if partners share the costs to solve societal challenges. Performance in terms of costs have been evaluated as seen in table 1 below.

Table 1. Pointers of Cost for KCCA in Solid waste management

\begin{tabular}{lll}
\hline Criteria & Performance indicators & Target \\
\hline Cost & (i) $\quad$ Cost solid waste & $\begin{array}{l}\text { Directors KCCA \& senior } \\
\text { officials. }\end{array}$ \\
& $-\quad$ Partnerships reduce costs & $\begin{array}{l}\text { Employees of KCCA in } \\
\text { public health department } \\
\text { - A greater capacity to serve a large client base leads }\end{array}$ \\
& reduction in the input prices & $\begin{array}{l}\text { Mayors } \\
\text { Deputy Mayor } \\
\text { proportion of cost falls }\end{array}$ \\
& Town Clerks \\
& - Reducing duplication leads to lower costs & \\
& costs of delivery services. & \\
& information &
\end{tabular}

Source: Researcher 


\subsection{Evaluating Quality in Solid Waste Management}

For solid waste services, this means the 'degree of excellence' in garbage management. Quality in general terms, simply means the expectations of the customer are met every single time. The customer has to be satisfied with the service you offer and preferably more than just satisfied. We measure quality in solid waste by looking at dimensions that drive the quality as shown in table below;

Table 2. Indicators of Quality for KCCA in Solid waste management

\begin{tabular}{lll}
\hline Criteria & Performance indicators & Target \\
\hline Quality & (i) $\quad$ Solid waste & $\begin{array}{l}\text { Directors KCCA \& } \\
\text { senior officials }\end{array}$ \\
& - Solid waste equipment (technology) & $\begin{array}{l}\text { Employees of KCCA } \\
\text { in public health } \\
\text { - Separtment Mayors, }\end{array}$ \\
- Selid waste treatment frequent & Deputy Mayor, Town \\
- Residization of public on waste & Clerks satisfaction SW achievements \\
- Interventions in solid waste & \\
- Status of solid waste (standards) & \\
- Effective waste management policy & \\
\hline & Division residents' positive behavior & \\
\hline
\end{tabular}

Source: Researcher

\subsection{Evaluating Social Welfare}

Social welfare in waste management can be measured through; programs, strategies, policy, satisfaction with activities, and response to welfare programs in different divisions.

The important performance indicators of social welfare and the target groups suggested as indicators to assess social welfare in KCCA are collected and shown in Table below;

Table 3. Indicators of Social welfare for KCCA in Solid waste management

\begin{tabular}{|c|c|c|}
\hline Criteria & Performance indicators & Target \\
\hline Social welfare & $\begin{array}{l}\text { (i) Welfare solid waste } \\
\text { - Low social class receive free garbage collection } \\
\text { services } \\
\text { - Welfare services are reliable } \\
\text { - There are strategies for social welfare services in solid } \\
\text { waste management } \\
\text { - Welfare policy is meeting people's expectation } \\
\text { - Solid waste management activities under welfare } \\
\text { programs satisfactory } \\
\text { - Responding well towards welfare services }\end{array}$ & $\begin{array}{l}\text { Directors KCCA \& } \\
\text { senior officials } \\
\text { Employees of KCCA } \\
\text { in public health } \\
\text { department } \\
\text { Mayors } \\
\text { Deputy Mayor } \\
\text { Town Clerks }\end{array}$ \\
\hline
\end{tabular}

Source: Researcher

The measurement dimensions of CQS discussed above are diagrammatically represented to form of a research frame work and it coordinates the elements of performance of shared services which has proved to be significant in broadening the scope of shared services on operational services which can be evaluated by the residents/electorate. 


\section{Research framework}

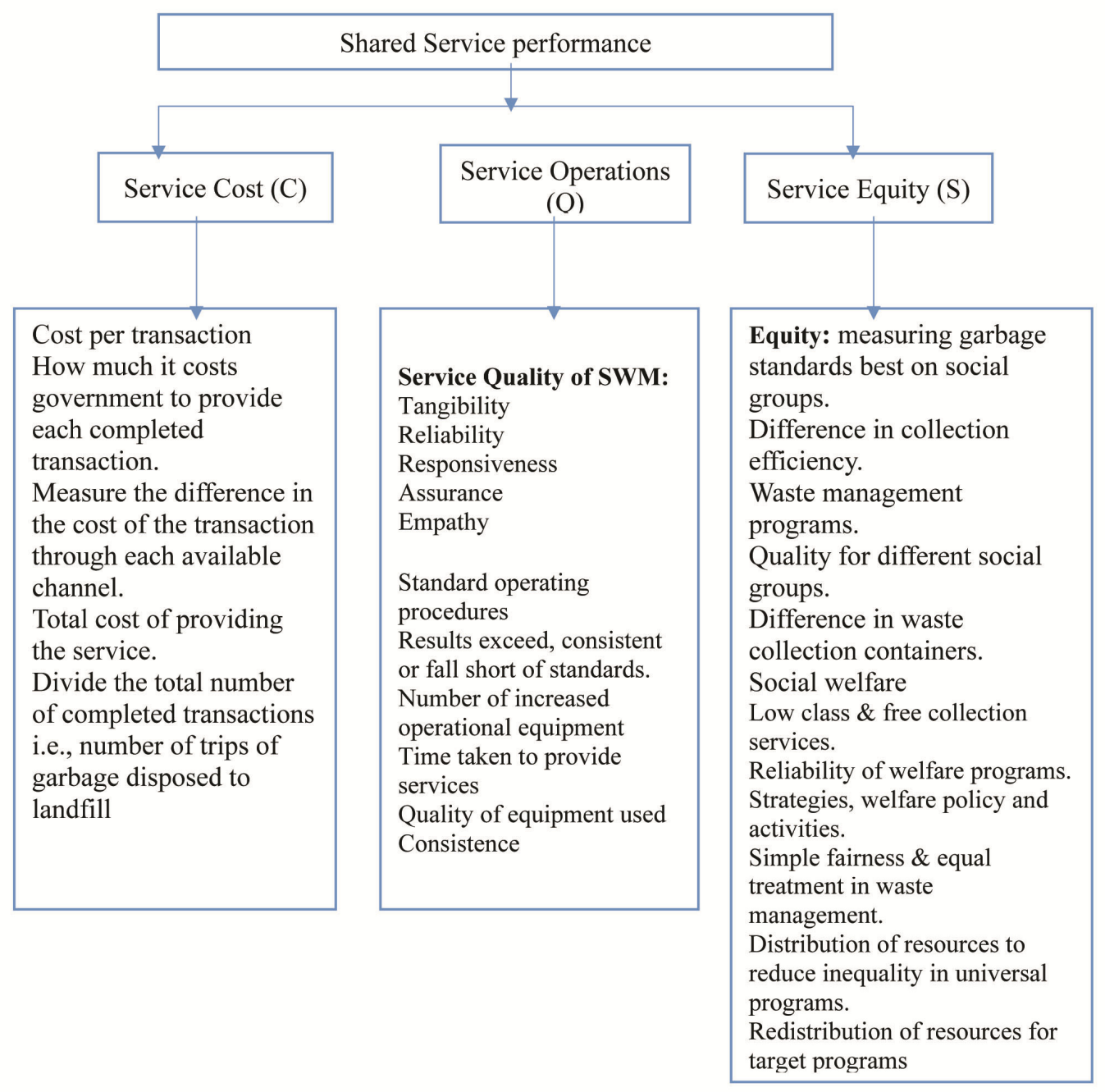

\section{Conclusion}

Previous studies have indicated different ways of measuring performance in public service institutions. The different approaches have been integrated to formulate a compound operational framework of CQS for evaluating shared service performance in public sector. The three elements are better than one in analyzing the outcome which is desirable and significant in the ongoing search for desire to improve performance in the public service around the globe and Uganda specifically.

The assessment of performance of public sector in KCCA, places emphasis hitherto on gray areas of assessing measures aimed at quantification of results to the maximum possible extent. It attempts to add to the academic debate surrounding the challenge of measuring performance of public service organizations by proposing an integrated analytical frame of cost, quality and social welfare (CQS),

The findings of this study will have practical implication for KCCA on the on-going performance oriented policies and programs as a whole in terms of; (i) improving the performance of service delivery, (ii) developing performance evaluation systems, and (iii) adapting new methods of performance.

This is a multifaceted study on one hand, it assesses the performance of shared services in KCCA, identifies the impact of shared services and provides feedback to the organization concerned, thus enabling improvements to be made in future policies and programs.

In short, the practical implications of this study will be used to develop better understanding of the dynamics that influence the management and effective performance of solid waste under KCCA in Uganda and to orient the 
performance system in order to effect improvements in the way these services are delivered. It is hoped that it would make a good start towards the concept of assessing shared services. Practically, it would facilitate the evaluation of performance of public service.

The findings of the study may enable public servants to take into consideration the importance of interrelationship as a result of sharing to design a shared service policy with the aim of gaining economies of scale, improve quality and social welfare.

The economic aspect is achieving performance gains through reducing costs, improving quality and social welfare can be answered by embracing Shared services suitable through attaining the similar goals minus giving up local democracy and performance can be measured by using an integrated framework of CQS.

\section{References}

Allan, P. (2003). Why Smaller Councils Make Sense. Australian Journal of Public Administration, 62(3), 74-81.

Allan, P., \& Movement, B. S. (2001). Secession: A manifesto for an independent Balmain local council: Balmain Secession Movement.

Andrews, R., \& Boyne, G. A. (2009). Size, structure and administrative overheads: An empirical analysis of English local authorities. Urban Studies, 46(4), 739-759.

Andrews, R., \& Entwistle, T. (2010). Does Cross-Sectoral Partnership Deliver? An Empirical Exploration of Public Service Effectiveness, Efficiency, and Equity. Journal of Public Administration Research \& Theory, 20(3), 679-701. http://dx.doi.org/10.1093/jopart/mup045

Bahia, S. R. (1996). Sustainability indicators for a waste management approach Consolidación para el desarrollo (pp. 1-11 [t. 15]): AIDIS.

Bangemann, T. O. (2005). Shared services in finance and accounting: Gower Publishing, Ltd.

Bergeron, B. (2002). Essentials of shared services (Vol. 13): Wiley.

Bergeron, B. (2003). Essentials of Shared Services. 2003: John Wiley \& Sons.

Boland, T., \& Fowler, A. (2000). A systems perspective of performance management in public sector organisations. International Journal of Public Sector Management, 13(5), 417-446.

Borins, S. (2001). The challenge of innovating in government: PricewaterhouseCoopers Endowment for the Business of Government Arlington, VA.

Boyne, G. A. (1996). Assessing party effects on local policies: a quarter century of progress or eternal recurrence? Political Studies, 44(2), 232-252.

Braveman, P. A. (2011). Monitoring equity in health and healthcare: a conceptual framework. Journal of Health, Population and Nutrition (JHPN), 21(3), 181-192.

Brown, T. L., \& Potoski, M. (2003). Transaction costs and institutional explanations for government service production decisions. Journal of Public Administration research and theory, 13(4), 441-468.

Brown, T. L., Potoski, M., \& Van Slyke, D. M. (2006). Managing Public Service Contracts: Aligning Values, Institutions, and Markets. Public administration review, 66(3), 323-331. http://dx.doi.org/10.1111/j.1540-6210.2006.00590.x

Buchanan, J. M. (1969). Cost and choice: An inquiry in economic theory: University of Chicago Press.

Buchanan, J. M., \& Tullock, G. (1965). The calculus of consent: Logical foundations of constitutional democracy (Vol. 100): University of Michigan Press.

Carr, J. B., LeRoux, K., \& Shrestha, M. (2009). Institutional ties, transaction costs, and external service production. Urban Affairs Review, 44(3), 403-427.

Carter, N., \& Greer, P. (1993). Evaluating agencies: Next Steps and performance indicators. Public Administration, 71(3), 407-416.

Chandra, P., Chu, Y.-H., Fisher, A., Gao, J., Kosak, C., Ng, T. E., . . Z Zhang, H. (2001). Darwin: Customizable resource management for value-added network services. Network, IEEE, 15(1), 22-35.

Chen, Y., \& Thurmaier, K. (2008). Interlocal agreements as collaborations: An empirical investigation of impetuses, 
norms, and success. The American Review of Public Administration. Pre-published October, 10, 2008. http://dx.doi.org/10.1177/0275074008324566

Cooke, F. L. (2006). Modeling an HR shared services center: Experience of an MNC in the United Kingdom. Human Resource Management, 45(2), 211-227.

Crosby, P. B. (1979). Quality is free: The art of making quality certain (Vol. 94): McGraw-Hill New York.

Deming, W. E. (1994). Report card on TQM. Management Review, 22-25.

Dolgoff, R., Feldstein, D., \& Skolnik, L. (1980). Understanding social welfare: Harper \& Row New York.

Dollery, B., Akimov, A., \& Byrnes, J. (2009). Shared services in Australian local government: rationale, alternative models and empirical evidence. Australian Journal of Public Administration, 68(2), 208-219.

Dollery, B., Byrnes, J., \& Crase, L. (2008). AUSTRALIAN LOCAL GOVERNMENT AMALGAMATION: A CONCEPTUAL ANALYSIS POPULATION SIZE AND SCALE ECONOMIES IN MUNICIPAL SERVICE PROVISION1. Australasian Journal of Regional Studies, 14(2), 167-175.

Dollery, B., Byrnes, J., Dollery, B., \& Robotti, L. (2008). Structural reform in Australia. The theory and Practice of Local Government Reform, Edward Elgar, forthcoming.

Dollery, B., \& Crase, L. (2004). Is bigger local government better? An evaluation of the case for Australian municipal amalgamation programs. Urban Policy and Research, 22(3), 265-275. http://dx.doi.org/10.1080/0811114042000269290

Dollery, B., \& Fleming, E. (2006). A Conceptual Note on Scale Economies, Size Economies and Scope Economies in Australian Local Government. Urban Policy and Research, 24(2), 271-282. http://dx.doi.org/10.1080/08111140600704111

Dollery, B., Goode, S., \& Grant, B. (2010). Structural Reform of Local Government in Australia: A Sustainable Amalgamation Model for Country Councils. Space and Polity, 14(3), 289-304. http://dx.doi.org/10.1080/13562576.2010.532979

Dollery, B., Grant, B., \& Akimov, A. (2010). A Typology of Shared Service Provision in Australian Local Government. Australian Geographer, 41(2), 217-231. http://dx.doi.org/10.1080/00049181003742310

Dollery, B., Grant, B., \& Kortt, M. (2012). Councils in cooperation: shared services and Australian local government.

Dollery, B., \& Johnson, A. (2005). Enhancing Efficiency in Australian Local Government: An Evaluation of Alternative Models of Municipal Governance1. Urban Policy and Research, 23(1), 73-85. http://dx.doi.org/10.1080/0811114042000335278

Dollery, B., Kortt, M., \& Grant, B. (2012). Options for rationalizing local government structure: a policy agenda: International Center for Public Policy (formerly the International Studies Program), Andrew Young School of Policy Studies, Georgia State University.

Dollery, B., \& Marshall, N. (2003). Future directions for Australian local government. Reshaping Australian Local Government: Finance, Governance and Reform, UNSW Press, Sydney, 231-250.

Dollery, B., Moppett, W., \& Crase, L. (2006). Spontaneous Structural Reform in Australian Local Government: the case of the Gilgandra Co-operative Model in New South Wales. Australian Geographer, 37(3), 395-409. doi: $10.1080 / 00049180600954807$

Drucker, P. F., \& Wilson, G. (2001). The essential drucker (Vol. 81): Butterworth-Heinemann Oxford.

Duncombe, W., \& Yinger, J. (2007). Does School District Consolidation Cut Costs? Education Finance and Policy, 2(4), 341-375. http://dx.doi.org/10.1162/edfp.2007.2.4.341

Feigenbaum, A. V. (1999). The new quality for the twenty-first century. The TQM magazine, 11(6), 376-383.

FOX, R., Fox, T. A., \& Anderson, R. C. (1991). Measuring the effectiveness of the Star Parenting Program with parents of young children. Psychological Reports, 68(1), 35-40.

Garvin, D. A. (1988). Managing quality: The strategic and competitive edge: Simon and Schuster.

Gershon, P. (2004). Releasing resources to the front line: Independent Review of Public Sector Efficiency: HM Stationery Office. 
Gershon's, S. P. (2004). Releasing resources to the front line.

Ghorpade, J. (1971). Assessment of organizational effectiveness.

Glendinning, C., Powell, M. A., \& Rummery, K. (2002). Partnerships, New Labour and the governance of welfare: Associated University Presse.

Gordon, V. (2009). Perceptions of Regional Economic Development: Can Win-Lose Become Win-Win? Economic Development Quarterly, 23(4), 317-328. http://dx.doi.org/10.1177/0891242409341972

Government, D. f. C. a. L. (2006a). Rethinking Service Delivery: Shared Service and Public/Public Partnerships London, HMSO DLCG. United Kingdom, Volume 3.

Government, D. f. C. a. L. (2006b). Structures for Collaboration and Shared Services Technical Notes. London, HMSO DLCG. United Kingdom.

Guo, C., \& Acar, M. (2005). Understanding collaboration among nonprofit organizations: Combining resource dependency, institutional, and network perspectives. Nonprofit and Voluntary Sector Quarterly, 34(3), 340-361.

Harris, S. E. (2010). The Deloitte \& Touche Merger Decision:: Lessons Learned from a Successful Merger. Organizational Dynamics, 39(3), 279-287.

Hawkins, C. (2010). Inter-jurisdictional economic development: A political institution explanation for policy choice. International Journal of Public Administration, 33(7), 379-389.

Hawkins, C. V. (2009). Prospects for and Barriers to Local Government Joint Ventures. State and Local Government Review, 41(2), 108-119. http://dx.doi.org/10.1177/0160323x0904100204

Hudson, B., Hardy, B., Henwood, M., \& Wistow, G. (1999). In pursuit of inter-agency collaboration in the public sector: What is the contribution of theory and research? Public Management an International Journal of Research and Theory, 1(2), 235-260.

Hogg, J. (2003). 'Getting the Most from an HR Shared Service Centre', Strategic HR Review, 2(4), 32-5.

Jackson, P. M. (1995). Measures for success in the public sector: CIPFA The Chartered Institute of Public Finance and Accountancy.

Jreisat, J. E. (1997). Public organization management: The development of theory and process. Quorum Books.

Juran, J. M. (1988). Juran on planning for quality. Free Press New York.

Lackey, S. B., Freshwater, D., \& Rupasingha, A. (2002). Factors Influencing Local Government Cooperation in Rural Areas: Evidence from the Tennessee Valley. Economic Development Quarterly, 16(2), 138-154. http://dx.doi.org/10.1177/0891242402016002004

Lasker, R. D., Weiss, E. S., \& Miller, R. (2001). Partnership synergy: a practical framework for studying and strengthening the collaborative advantage. Milbank quarterly, 79(2), 179-205.

LeRoux, K. (2008). Nonprofit community conferences: The role of alternative regional institutions in interlocal service delivery. State and Local Government Review, 40(3), 160-172.

LeRoux, K., \& Carr, J. B. (2007). Explaining Local Government Cooperation on Public Works Evidence From Michigan. Public Works Management \& Policy, 12(1), 344-358.

Leroux, K., \& Carr, J. B. (2007). Explaining Local Government Cooperation on Public Works: Evidence From Michigan. Public Works Management \& Policy, 12(1), 344-358. http://dx.doi.org/10.1177/1087724x07302586

Lombard, J. R., \& Morris, J. C. (2010). Competing and Cooperating across State Borders in Economic Development A Call for "Coopertition". State and Local Government Review, 42(1), 73-81.

Lusthaus, C. (2002). Organizational assessment: A framework for improving performance: IDRC.

Madinah, N., Boerhannoeddin, A., \& Rriffin, R. N. B. R. (2014). Performance Assessment of Public Service Organisations in Shared Solid Waste Services: A case for Kampala Capital City Authority in Uganda. World Journal of Social Science, 1(2), p86.

McKinlay, P. (2011). Reconceptualising Shared Services. Commonwealth Journal of Local Governance (8/9).

McQuaid, R. W., \& Scherrer, W. (2010). Changing reasons for public-private partnerships (PPPs). Public Money \& Management, 30(1), 27-34. 
Mitchell, G., May, A., \& McDonald, A. (1995). PICABUE: a methodological framework for the development of indicators of sustainable development. The International Journal of Sustainable Development \& World Ecology, 2(2), 104-123.

Moharir, V. (1997). Policy Implementation: Operational Capability and Administrative Performance. Unpublished manuscript, Den Haag: Institutes of Social Studies..(1997b). Tutorials on Policy Implementation. Den Haag: Institute of Social Studies.

Mulreany, M. (1991). Economy, efficiency, and Effectivness in the Public Sector: Key Issues. 1991) Efficiency and Effectiveness in the Public Domain, Dublin: Institute of Public Administration.

Murray, J. G., Rentell, P. G., \& Geere, D. (2008). Procurement as a shared service in English local government. The International Journal of Public Sector Management, 21(5), 540-555. doi: http://dx.doi.org/10.1108/09513550810885822

NAO, N. A. O. (2007). Value for money in public sector corporate services.: A joint project by the UK public sector audit agencies. London, National Audit Office. United Kingdom.

Niehaves, B., \& Krause, A. (2010a). Shared service strategies in local government-a multiple case study exploration. Transforming Government: People, Process and Policy, 4(3), 266-279.

Niehaves, B., \& Krause, A. (2010b). Shared service strategies in local government - a multiple case study exploration. Transforming Government: People, Process and Policy, 4(3), 266-279.

O'Leary, R., Gerard, C., \& Bingham, L. B. (2006). Introduction to the symposium on collaborative public management. Public administration review, 66(s1), 6-9.

Oakerson, R. J. (1999). Governing local public economies: Creating the civic metropolis: ICS Press Oakland, CA.

Osborne, D. (1993). Reinventing government. Public Productivity \& Management Review, 349-356.

Osborne, D., \& Gaebler, T. (1992). Reinventing Government: How the entrepreneurial spirit is transforming the public sector. 1992. HARV. BLACKLETTER J., 9, 163.

Osborne, S. P., \& Brown, K. (2005). Managing change and innovation in public service organizations (Vol. 1): Psychology Press.

Parasuraman, A., Zeithaml, V., \& Berry, L. (1988). Refinement and reassessment of the SERVQUAL scale.

Piening, E. P. (2011). Insights into the process dynamics of innovation implementation. Public Management Review, 13(1), 127-157.

Pike, T. (2012). An exploration of how shared corporate service operate and perform in English local government. Cardiff University.

Quinn, B., Cooke, R. S., \& Kris, A. (2000). Shared services: mining for corporate gold: Financial Times Prentice Hall.

Ramanujam, V., Venkatraman, N., \& Camillus, J. C. (1986). Multi-objective assessment of effectiveness of strategic planning: a discriminant analysis approach. Academy of management Journal, 29(2), 347-372.

Redman, T., Snape, E., Wass, J., \& Hamilton, P. (2007). Evaluating the human resource shared services model: evidence from the NHS. The International Journal of Human Resource Management, 18(8), 1486-1506.

Robbins, S., \& Coulter, M. (1996). Find management. Bellingham, WA: Prentice Hall College Division.

Ruggini, J. (2006). Making Local Government More Workable through Shared Services. Government Finance Review, 22(1), 30-35.

Shah, A. (2003). Handbook of public sector performance review. World Bank.

Shakrani, S. M. (2010). School District Consolidation Study In 10 Michigan Counties. Michigan State University.(February 2010).

Shakrani, S. M. (2010). School District Consolidation Study in 10 Michigan Counties. Education Policy Center at Michigan State University. http://media. mlive. com/news_impact/other/textreport. pdf

Smith, A., Rainnie, A., Dunford, M., Hardy, J., Hudson, R., \& Sadler, D. (2002). Networks of value, commodities and regions: reworking divisions of labour in macro-regional economies. Progress in Human Geography, 26(1), 41-63. 
Smith, P. (1995). Performance indicators and outcome in the public sector. Public Money \& Management, 15(4), 13-16.

Solutions, S. (2005). Shared Services as a Long-term Solution for Local Government: Delivering on the Gershon Report. Serco Solutions (September 2005).

Sørensen, R. J. (2006). Local government consolidations: The impact of political transaction costs. Public Choice, 127(1-2), 75-95.

Symons, T., Roth,O., \& Sturge, J. . (2011). Shared Necessities: The generation of Shared Services New Local Government Network.

Telegraph, U. K. (2011). Quality public goods and opening the platform to competition telegraph.co.uk/news/politics, 2011.

Tomkinson, R. (2007). Shared services in local government: improving service delivery: Gower Publishing Company.

Turrini, A., Cristofoli, D., Frosini, F., \& Nasi, G. (2010). Networking literature about determinants of network effectiveness. Public Administration, 88(2), 528-550.

Ulbrich, F. (2003). Introducing a research project on shared services in governmental agencies. Paper presented at the 17th Scandinavian Academy of Management (NFF) Conference.

Ulbrich, F. (2010). Adopting shared services in a public-sector organization. Transforming Government: People, Process and Policy, 4(3), 249-265.

Warner, M., \& Hebdon, R. (2001). Local government restructuring: Privatization and its alternatives. Journal of Policy Analysis and Management, 20(2), 315-336.

Warner, M. E., \& Bel, G. (2008). Competition or monopoly? Comparing privatization of local public services in the US and Spain. Public Administration, 86(3), 723-735.

Yee, H. W. J. (2009). Assessing the potential of inter-organisational shared services.

\title{
Appendix
}

\section{UNIVERSITY MALAYA- MALAYSIA \\ DEPARTMENT OF ADMINISTRATIVE STUDIES AND POLITICS \\ IMPROVING SERVICE DELIVERY: A CASE FOR SHARED SERVICES IN KCCA \\ QUESTIONNAIRE FOR RESIDENTS}

\begin{abstract}
QUESTIONNAIRE ON QUALTY OF SERVICE DELIVERED IN DIVISIONS BY KAMPALA CAPITAL CITY AUTHORITY IN TERMS OF SOLID WASTE MANAGEMENT SERVICES.
\end{abstract}

\begin{abstract}
This questionnaire is prepared for assessing the residents' opinion on the quality of services delivered by Kampala City Capital Authority in Kampala in terms of solid waste and garbage collection. The information sought from you is purely for academic purposes, and data may also help in improving the quality of service delivery at KCCA. Your cooperation will be highly appreciated, and your response will be treated with outmost confidentiality. Therefore, please feel free to answer the questions. Thank you.

\section{INSTRUCTIONS ON HOW TO COMPLETE THIS QUESTIONNAIRE.}

i. Read the following carefully before completing the questionnaire.

ii. Please circle/indicate the correct option(s).

iii. Your own view/opinion (based on your view or practical experience) will also be requested. In such cases please write the required information in the space provided.
\end{abstract}

\section{SECTIONA}

The purpose of this section is to get personal information of the respondent. 


\subsection{BIOGRAPHICAL DATA_}

\subsection{Division}
(a) Central
(b) Nakawa
(b) Lubaga
(d) Makindye
(e) Kawempe

1.2 Gender
(a) Male
(b) Female

1.3 Marital status
(a) Married
(b) Single
(c) Separated
(d) Other

1.4 Age
(a) $20-29$
(b) $30-39$
(c) $40-49$
(d) $50-59$
(e) $60-69$
(f) $70+$

1.5 Highest Educational Qualification
(a) Primary
(b) Secondary
(c) Certificate
(d) Diploma
(e) Bachelor's Degree
(f) Masters
(g) $\mathrm{PhD}$

1.6 The sector the person is employed
(a) Gov't service
(b) Employed by private sector
(c) Self-employed
(d) House wife (e) Others please specify

1.7 The level of income per month
(a) Less than 500,000
(b) $500,001-1,000,000$
(c) $1,000,001-1,500,000$
(d) $1,500,001-2,000,000$
(e) More than 2,000,000

1.8 Length of Stay in the division.
(a) $<5$ years
(b) 6 - 10 years
(c) $11-15$ years
(d) $>15$ years

1.9 Please choose the type of housing setup that you live in
(a) Upper scale housing
(b) Planned housing estate
(c) Unplanned housing set up
(d) Town flats
(e) Slums

\section{SECTION B}

Objective of this section is to seek the respondents' view/opinion on KCCA service delivery in areas of solid waste management and garbage collection. Please indicate the appropriate answer

2.1 Does KCCA provide solid waste management and garbage collection to all the residents?
(a) Yes
(b) No
(c) Not Sure

2.2 If your answer is yes in 3 above, how well is the KCCA solid waste management and garbage collection system?
(a) Very well
(b) Well
(c) Quite Well
(d) Somewhat well
(e) Fairly
(f) Somewhat poor
(g) Quite poorly
(h) poorly
(i) Very poorly

\section{Solid waste and garbage collection management}

2.27 Which among the following are the types of wastes generated in Kampala? (Indicate all that apply)
(a) Domestic waste
(b) Commercial waste
(c) Industrial waste
(d) Institutional waste
(e) Market waste
(f) Hospital waste

2.28 What is the most common way for residents to dispose their waste? (Indicate all that apply)
(a) Burn the waste
(b) Place in garbage containers (communal collection)
(c) Dump at the roadside
(d) Use formal collectors (contracted companies)
(e) Use informal collectors (individual)
(f) Use NGOs
(g) Others

2.29 Select any safe waste disposal method used at KCCA among the following; (Indicate all that apply)
(a) Land filling (at Kitezi)
(b) Incineration (industrial burning)
(c) Composting (manure making)
(d) Recycling
(e) All the above

2.30 Which is the common means of waste collection used by KCCA?

(a) Waste collection \& transport vehicles

(b) Sealed compact vehicles 

(c) Formal agents (hired) trucks
(d) Garbage collectors (individuals)
(e) All the above

2.31 Is sold waste collection a free service in your division?
(a) Yes
(b) No
(c) Not sure

2.32 If your answer is No in 4.6 above, how much do you spend per month on solid waste collection?
(a) $5000-10000 /-$
(b) $15000-20000 /-$
(c) $20000-30000 /-$
(d) More than 30,000/-

2.33 If your answer is yes in 4.6 above, how far are the garbage containers from your home?
(a) Less than 100 meters
(b) $200 \mathrm{~m}$ to $500 \mathrm{~m}$
(c) $500 \mathrm{~m}$ to $1 \mathrm{~km}$
(d) $1 \mathrm{~km}$ to $2 \mathrm{~km}$
(e) more than $2 \mathrm{~km}$

2.34 To what extent do you agree that the landfill at Kitezi and waste collection transport vehicles cause additional pollution?
(a) Strongly agree
(b) Agree
(c) Quite agree
(d) Somewhat agree
(e) Neutral
(f) Somewhat disagree
(h) Quite disagree
(i) Disagree
(j) Strongly disagree

2.35 Does KCCA have enough solid waste collection and management facilities \& equipment?
(a) Yes
(b) No
(c) Not sure

2.36 If your answer is No in 2.35 above, what among the following do you think explains this? (Indicate all that apply)
(a) Lack of funds
(b) Lack of capacity
(c) Poor management
(d) Lack of solid waste collection and garbage management policy
$\begin{array}{ll}\text { (e) Misuse of facilities and equipment } & \text { (f) No technical capacity }\end{array}$

2.37 In your opinion do, you think shared solid waste collection and garbage management services among divisions can improve the delivery of this expensive service?
(a) Yes
(b) No
(c) Not sure

2.38 If your answer in 2.37 above is Yes, which among the following justifies shared solid waste collection and garbage management services among divisions (Indicate all that apply)
a) Generation of sufficient resources
(b) Shared costs
(c) Reduced costs
(d) Improve service delivery
(e) Improve on the equity
(f) Improve on the effectiveness
(g) Economies of scale
(h) Improve quality
(i) Improve standards
(j) Improve Social Welfare

2.39 In your opinion, what is the most positive aspect of sharing solid waste services among the following? (Indicate all that apply)
a) Increase in the collection rate
(b) Increase Sanitation
(c) Reduce diarrhea
(d) Proper transportation and treatment (e) Sensitization waste program

2.40 In your opinion, what is most serious problem encountered in sharing solid waste services among division from the list below? (Indicate all that apply)
a) Lack of coordination
(b) Untrusted partners
(c) Stake holder involvement
(d) Lack of shared vision
(e) Unequal distribution of resources
(h) Poor communication

2.41 Do you think that sharing of solid waste collection and garbage management services improves service delivery greatly in the divisions?
(a) Yes
(b) No
(c) Not sure

2.42 If your answer in 2.41 above is Yes, state the aspect in which it improves service delivery.

2.43 Do you agree that KCCA should encourage and support the shared services initiatives among the divisions?
(a) Yes
(b) No
(c) Not sure 
2.44 Do you think that sharing of solid waste collection and garbage management services improves service quality greatly in the divisions?
(a) Yes
(b) No
(c)Not sure

2.45. Do you think that sharing of solid waste collection and garbage management services improves community satisfaction greatly in the divisions?
(a) Yes
(b) No
(c)Not sure

2.46 Do you think that sharing of solid waste collection and garbage management services improves performance?
(a) Yes
(b) No
(c)Not sure

\section{SECTION C}

The purpose of this section is to investigate the community (residents) views on service delivery in terms solid waste and garbage collection under partnership and cooperation.

A number of statements regarding the residents' views towards service delivery under partnership in your division are presented below. Five possible reactions ranging from Strongly agree (1), Agree (2), Neutral (3), Disagree (4) to Strongly disagree (5) are listed under each statement. Please choose the alternative in which the answer that comes closest to the level of your satisfaction, and tick the appropriate choice.

\begin{tabular}{|c|c|c|c|c|c|c|}
\hline \multicolumn{2}{|r|}{ Shared services } & & & & & \\
\hline $\mathbf{A}$ & Shared services & & & & & \\
\hline 1 & Shared services help to generate sufficient resources. & 1 & 2 & 3 & 4 & 5 \\
\hline 2 & Through shared services partners share all the costs & 1 & 2 & 3 & 4 & 5 \\
\hline 3 & Shared services reduce on the costs of service delivery. & 1 & 2 & 3 & 4 & 5 \\
\hline 4 & Shared services leads to improved service delivery. & 1 & 2 & 3 & 4 & 5 \\
\hline 5 & Shared services leads to effectiveness of service delivery. & 1 & 2 & 3 & 4 & 5 \\
\hline 6 & Shared services improves the quality of service delivery. & 1 & 2 & 3 & 4 & 5 \\
\hline 7 & Shared services aim at high standards of performance. & 1 & 2 & 3 & 4 & 5 \\
\hline 8 & Shared services improve on the equity of service delivery. & 1 & 2 & 3 & 4 & 5 \\
\hline 9 & Shared services enable the reduction of per unit cost of service delivery. & 1 & 2 & 3 & 4 & 5 \\
\hline 10 & Shared services partnerships improve on social welfare. & 1 & 2 & 3 & 4 & 5 \\
\hline 11 & There is lack of coordination among partners under the shared service arrangement & 1 & 2 & 3 & 4 & 5 \\
\hline 12 & There are always untrusted partners in the shared service arrangement. & 1 & 2 & 3 & 4 & 5 \\
\hline 13 & There is lack of involvement and participation among all the partners in the shared service arrangement. & 1 & 2 & 3 & 4 & 5 \\
\hline 14 & No all partners have the same shared vision. & 1 & 2 & 3 & 4 & 5 \\
\hline 15 & There is unequal distribution of resources among partners in the shared service arrangement. & 1 & 2 & 3 & 4 & 5 \\
\hline 16 & There is always poor communication among partners in shared service arrangement. & 1 & 2 & 3 & 4 & 5 \\
\hline 17 & KCCA should encourage and support the shared service initiatives among the divisions & 1 & 2 & 3 & 4 & 5 \\
\hline
\end{tabular}




\section{SECTION D}

\section{SHARED SERVICES}

The objective of this section is to assess the respondents' views in relation to cost, quality and social welfare of Solid waste management and garbage collection of Kampala City Capital Authority.

Key: depending on the statement, the scale of change or achievement ranges can either be in agree, satisfied/satisfactory or acceptable for example agree range from Strongly disagree (1), disagree (2), somehow disagree (3), slightly disagree (4), neutral (5), slightly agree (6) somehow agree (7) quite agree (8), Agree (9) to Strongly agree (10). Answer the questions frankly by circling the correct answer in the box that is closest to your level of agreement with the statement /question.

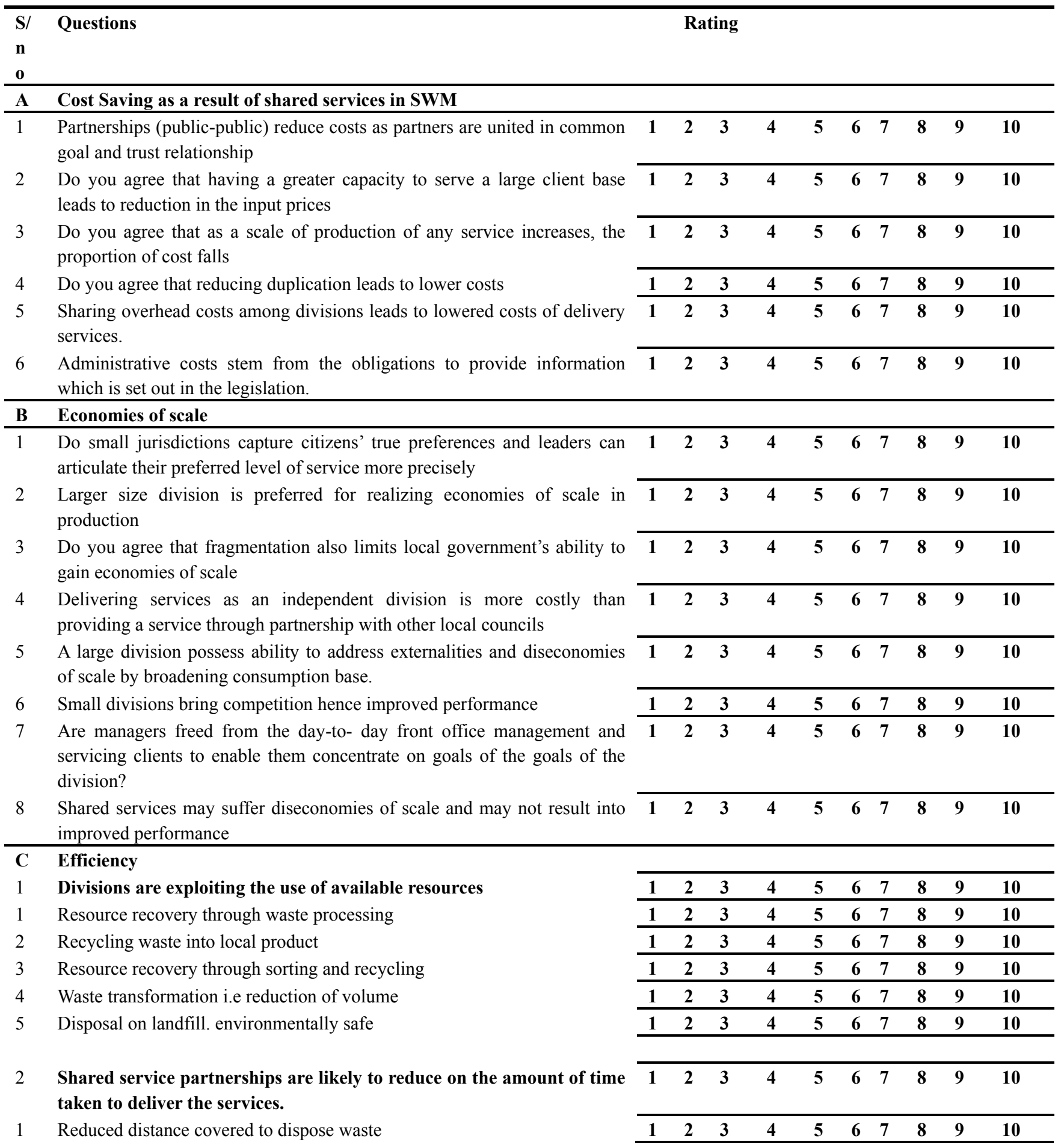


2 Waste containers are fairly distributed

3 Improved mode of collection of waste

4 Involvement of many government agencies

5 Waste is collected in reasonable time periods

3 Shared service partnerships have enabled divisions to carry out their respective policies and plans in a more efficiently.

1 Achievement of integrated waste management planning

2 Implementation of solid waste ordinance 2000

3 The right of an individual to information on waste

4 Safety for the waste collectors and the residents

5 Effective monitoring of compliance with the national standards

\begin{tabular}{llllllllll}
\hline 1 & 2 & 3 & 4 & 5 & 6 & 7 & 8 & 9 & 10 \\
\hline 1 & 2 & 3 & 4 & 5 & 6 & 7 & 8 & 9 & 10 \\
\hline 1 & 2 & 3 & 4 & 5 & 6 & 7 & 8 & 9 & 10 \\
\hline 1 & 2 & 3 & 4 & 5 & 6 & 7 & 8 & 9 & 10 \\
\hline 1 & 2 & 3 & 4 & 5 & 6 & 7 & 8 & 9 & 10
\end{tabular}

\section{Effectiveness}

1 Public-public partnerships will be apparent in the effective measurement of performance

2 The success of share services is greatly dependent on how effective is the implementation process

3 Shared service arrangements will not gain from high levels supervision

4 Shared service arrangement will gain from high trust of the partners in the partnership

5 The partnership dissolves due to selfish interests of the agent and failure to

\begin{tabular}{|c|c|c|c|c|c|c|c|c|c|}
\hline 1 & 2 & 3 & 4 & 5 & 6 & 7 & 8 & 9 & 10 \\
\hline 1 & 2 & 3 & 4 & 5 & 6 & 7 & 8 & 9 & 10 \\
\hline 1 & 2 & 3 & 4 & 5 & 6 & 7 & 8 & 9 & 10 \\
\hline 1 & 2 & 3 & 4 & 5 & 6 & 7 & 8 & 9 & 10 \\
\hline 1 & 2 & 3 & 4 & 5 & 6 & 7 & 8 & 9 & 10 \\
\hline
\end{tabular}
deliver the services

6 Partnerships are also affected by too much control and supervision

$7 \quad$ Distrust can lead to dissolving of the partnership

\begin{tabular}{llllllllll}
1 & 2 & 3 & 4 & 5 & 6 & 7 & 8 & 9 & 10 \\
\hline 1 & 2 & 3 & 4 & 5 & 6 & 7 & 8 & 9 & 10
\end{tabular}

\section{E Welfare}

1 Low social class receive free garbage collection services in the different divisions

2 Welfare services are reliable in the divisions

3 There are strategies for social welfare in divisions

4 Welfare policy is meeting people's expectation

5 SWM activities under welfare programs satisfactory

6 Division are responding well towards welfare services

\section{Quality}

1 There is improvement in technology use in the management of garbage

2 Waste treatment done frequently

3 Quality of tools and equipments used in garbage collection Frequency in collection of garbage

\begin{tabular}{llllllllll}
\hline 1 & 2 & 3 & 4 & 5 & 6 & 7 & 8 & 9 & 10 \\
\hline 1 & 2 & 3 & 4 & 5 & 6 & 7 & 8 & 9 & 10 \\
\hline
\end{tabular}

\begin{tabular}{llllllllll}
\hline 1 & 2 & 3 & 4 & 5 & 6 & 7 & 8 & 9 & 10
\end{tabular}

\begin{tabular}{llllllllll}
\hline 1 & 2 & 3 & 4 & 5 & 6 & 7 & 8 & 9 & 10 \\
\hline 1 & 2 & 3 & 4 & 5 & 6 & 7 & 8 & 9 & 10 \\
\hline
\end{tabular}

Residents are satisfied with the achievements of solid waste collection and garbage management services in Kampala

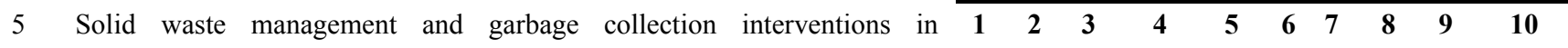
improving service delivery are good

6 The status of the solid waste management and garbage collection services in KCCA is good

7 There is an effective solid waste generation policy in place.

8 Division residents' behavior toward waste generation change is good.

9 The solid waste and garbage collection management systems in place are environmentally friendly

\section{Quantity}

1 The number and spacing of solid waste collection containers is good

2 Solid waste management and garbage collection under partnerships increased the amount of equipments.

\begin{tabular}{llllllllll}
\hline 1 & 2 & 3 & 4 & 5 & 6 & 7 & 8 & 9 & 10 \\
\hline 1 & 2 & 3 & 4 & 5 & 6 & 7 & 8 & 9 & 10 \\
\hline 1 & 2 & 3 & 4 & 5 & 6 & 7 & 8 & 9 & 10 \\
\hline 1 & 2 & 3 & 4 & 5 & 6 & 7 & 8 & 9 & 10 \\
\hline 1 & 2 & 3 & 4 & 5 & 6 & 7 & 8 & 9 & 10 \\
\hline & & & & & & & & & \\
\hline 1 & 2 & 3 & 4 & 5 & 6 & 7 & 8 & 9 & 10 \\
\hline 1 & 2 & 3 & 4 & 5 & 6 & 7 & 8 & 9 & 10 \\
\hline 1 & 2 & 3 & 4 & 5 & 6 & 7 & 8 & 9 & 10 \\
\hline 1 & 2 & 3 & 4 & 5 & 6 & 7 & 8 & 9 & 10 \\
\hline 1 & 2 & 3 & 4 & 5 & 6 & 7 & 8 & 9 & 10
\end{tabular}

\section{Standardization}




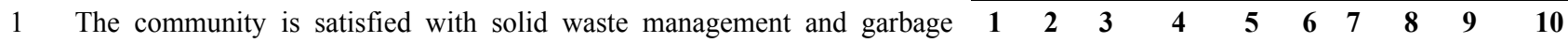
collection standards in KCCA.

2 The changes in the standards of waste management services in the $\begin{array}{lllllllllllllllll}\mathbf{1} & \mathbf{2} & \mathbf{3} & \mathbf{4} & \mathbf{5} & \mathbf{6} & \mathbf{7} & \mathbf{8} & \mathbf{9} & \mathbf{1 0}\end{array}$ divisions have improved like in technology.

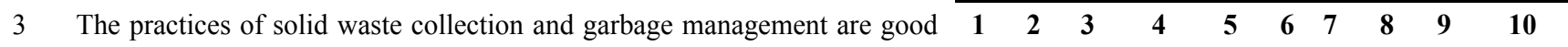
in the divisions after the partnership arrangement.

4 There is a complaint process for any dissatisfaction with solid waste $\begin{array}{cccccccccccccccccc} & \mathbf{2} & \mathbf{3} & \mathbf{4} & \mathbf{5} & \mathbf{6} & \mathbf{7} & \mathbf{8} & \mathbf{9} & \mathbf{1 0}\end{array}$ collection and garbage management in the division.

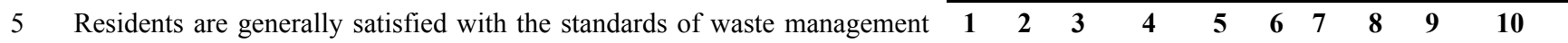
in divisions

\section{Equity}

1 All different social classes of people receive waste management services from the divisions

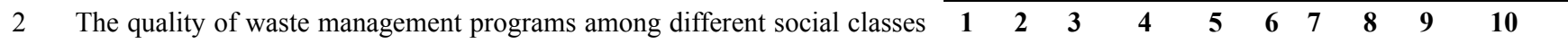
in the divisions is good.

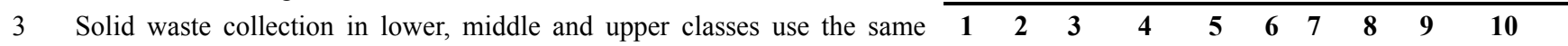
techniques in the division

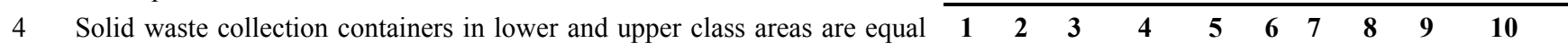
and same.

\section{End of the Questionnaire}

Thank you 